\title{
Evaluation of motivation system in Health Care Organization - perception of employees. A case study analysis from Polish hospital
}

\section{Introduction}

In a time that features aging populations in Europe, the Health Care Sector plays a significant role in each country's strategy to improve the health and well-being of the workforce and its society as a whole. In the context of demographic change, the importance of this sector is going to grow, and both demand for health care workers as well as shortages in staff are expected to increase (Bartkowiak 2008; Karaszewska, Nieżurawska 2013; Report of the European Foundation... 2009). The health care sector is also a significant work provider, as it currently employs over $20 \%$ of the workforce; this number is expected to grow even more in the near future. Employment in this sector has increased over the last decade, although some countries such as Poland witnessed a decline (Report of the European Foundation... 2009). It is important to note that, in most countries, health care can be characterized by the predominance of women working in the sector. Unfortunately, many of these women do not return to work following childbirth, as they have many difficulties balancing work and family duties. In Germany, for example, $80 \%$ of workers in the sector leave their jobs within five years (Report of the European Foundation... 2009). This situation may be the result of permanent changes, low wages, and difficult working conditions in some countries, including Poland (Bartkowiak 2008; Karaszewska, Nieżurawska 2013). One of the major reasons for the problem of employee retention might be an ineffective motivational system as

\footnotetext{
* AGH University of Science and Technology.

** The $5^{\text {th }}$ Military Hospital with Polyclinic in Krakow.
} 
well as the low quality of working conditions in health care (Bartkowiak 2008; Karaszewska, Nieżurawska 2013). Moreover, the lack of support in the working environment due to limited career opportunities, a stressful workplace, and sometimes even the threat of harassment and violence (often from patients and/or their relatives) might be another reason for the difficult situation within the health care sector.

In this context, a motivational environment seems to be crucial in terms of hiring and retaining skilled employees as well as assuring a high quality of services. The work done by medical staffs is extremely responsible and stressful, so it is vital to support such employees in their everyday work. Especially in Poland, where the health care sector has undergone critical organizational and financial changes, the creation of highly motivating conditions ought to be a priority (Bartkowiak 2008; Golinowska et al. 2002; Kautsch 2010; Dz. U., 2007 r., Nr 14, poz. 89; Dz. U. 2009 r., Nr 219, poz. 1708). Unfortunately, employers that represent the heath care sector in Poland seem to be unaware of the problem (Bartkowiak 2008; Karaszewska, Nieżurawska 2013).

Therefore, the aim of this article is to stress the importance of creating a supportive work environment in the health care sector. This paper researches the effectiveness of the motivational system in the health care sector in Poland and will show the results of an analysis of the aforementioned system being provided in one of the Polish Hospitals - the $5^{\text {th }}$ Military Hospital with Polyclinic in Krakow.

\section{Literature review}

Although an evaluation of the motivational system and practices seems to be important to employers, few studies have measured the effectiveness of motivational practices. According to research, a failure to evaluate motivation systems is due to a variety of factors, including the lack of awareness and conviction of the need for such analyses among managers and executives (Borkowska 2012; Brown 2008; Corby, White et al. 2005); the lack of resources, time, and specific information (Armstrong, Brown et al. 2011; Armstrong, Cummins 2010; Scott, Morajda et al. 2006); the lack of knowledge and experience of the professionals (Beck-Krala 2013; Brown 2008); and finally, the lack of reliable measures (Brown 2008).

Motivating employees and creating a supportive work environment is extremely important in all organizations. An effective motivational system will help to hire and retain well-qualified and talented employees, achieve desired results through individuals and teams, maintain consistent high performance, and finally achieve organizational goals (Borkowska 2012; Juchnowicz 2011; Kopertyńska 
2004). The crucial issues are how to make an organization more effective through a motivational system and how to improve the quality of working lives experienced by employees.

Frederick Herzberg's Theory of Motivation (1959) best explains the importance of both the motivators and the role of a supportive work environment. According to the author, satisfaction from the motivators and avoidance of problems with hygiene factors can help to improve performance and give individuals greater job satisfaction. Herzberg identified the six motivating factors that lead to job satisfaction as: achievement, recognition, the possibility of growth, advancement, responsibility, and the work itself. Whereas the hygiene factors which can create job disappointment are: company policy and administration, supervision, interpersonal relationships, salary, status, job security, working conditions, and personal life (Beck-Krala 2013; Kopertyńska 2004). The hygiene factors are those in which people try to avoid particular situations, whereas the motivating factors are matched with people's needs to achieve self-actualization or self-realization. Herzberg's work was further developed by other authors; for example, Leszek Kozioł (2011) who has modified Herzberg's approach into the Tracheotomy of Motivation Factors (Beck-Krala 2013). As L. Koziol noted, there are other factors in the workplace apart from the motivational and hygiene factors - these are called demotivating factors. According to this concept, there are three types of factors (Beck-Krala 2013):

- motivators (cause employee satisfaction),

- hygiene factors (a lack of them affects the satisfaction of employees),

- demotivators (demotivates employees when present in the work environment).

Demotivators are defined as factors that reduce the motivation to work, or cause reluctance or unwillingness to work efficiently. These mainly include bullying, workplace stress, excessive workload, tasks beyond the abilities of the employee, short-term contracts, introducing changes, and more. Kozioł's findings seem to be very important when analyzing the situation of the health care sector, as some demotivators are permanently present, like: high pressure and stress among the medical staff as well as the introduction of organizational changes resulting from changes in legislation in Poland (Karaszewska, Nieżurawska 2013).

To analyze the motivational system, it is important to rely on adequate instruments and measurements. In the literature, there are few methods for evaluating the motivational system of an organization. Bogusz Mikuła and Arkadiusz Potocki show such tools as: the Lawler and Nadler Method, methods for determining the type of organizational climate, the checklist for assessment of the work arduousness in positions of the administrative sphere, the Blum and Russ Method. or the Hidden Cost Method (Mikuła 2001, pp. 109). However, only the method of Lawler and Nadler focus strictly on the motivational system and assess 
the system in a comprehensive manner. Other authors propose the use of the Donald Kirkpatrick evaluation scheme; however, this is a relatively general tool and needs a further selection of specific indicators (Armstrong, Cummins 2010, Scott, Morajda et al. 2006). In the literature, the Balanced Scorecard is also mentioned as a possible instrument to evaluate the motivational system (Beck-Krala 2013). However, previous implementation of this tool by organization management is required, as is the monitoring of results over time.

When analyzing specific indicators, the most-commonly used measures of evaluation in many organizations are the subjective opinions of managers or employees regarding the effectiveness of the motivational system (Brown 2008; Scott, Morajda et al. 2006), employee turnover rates, or employee satisfaction surveys (Scott, Morajda et al. 2006). However, the surveys must be evaluated by professionals in an appropriate way.

From the methods mentioned above, the most adopted in the health care sector seems to be the approach of Lawler and Nadler, as it has been designed exclusively for analysis of the motivational system. Furthermore, it combines the most popular measures - both the opinions of employees as well as some objective measures. Of course, this method has its drawbacks, as it does not provide clear guidance on how to proceed in the future but shows only general problematic issues in the study.

\section{Methodology}

When evaluating the motivational system with the Nadler and Lawler methodology, it is important to understand how the approach was developed. The main aim of this method is to diagnose the problems of organizational motivation by determining the attitudes of individual workers. This method helps to detect major errors and understand the problems of motivation.

The effectiveness of the motivational system in this tool is determined by "the degree of convergence between the expectations of employees and what they can get from the organization" (Mikuła 2001 pp. 22). Employers who study the needs of workers in this regard derive incentives in line with the expectations of employees, which in turn pays employee behaviors aimed at the implementation of the objectives and achieve job satisfaction. Therefore, if the system regards the needs of employees, it creates higher employee engagement and job satisfaction of employees, and thus raises their loyalty to the employer. In contrast, a significant discrepancy leads to undesirable behaviors at work as well as pathological mental state employees, which among medical personnel is particularly dangerous (Mikuła 2001 pp. 22). 


\subsection{The research tool}

The Lawler and Nadler approach was primarily based on the Michigan Assessment of Organizations' attitude survey. It was later modified and simplified by the authors and other professionals (Mikuła, 2001). This method is used to measure attitudes of individual employees in the organization by measuring the level of satisfaction against their expectations. The questionnaire consists of three parts: $\mathrm{A}, \mathrm{B}$, and $\mathrm{C}$.

Part A is used to identify the general situation in the motivational system in the organization. This section shows what employee can expect in return from an organization for high performance and individual commitment.

Part B is used to identify the needs of the individual employee. It contains a description of the seventeen benefits that the employee can receive from work. In this section, an employee assesses the value of each benefit.

The analysis of gathered data in these two parts is done by comparing the responses of part A and B in the questionnaire. Numerical indicators that help interpreting the data are used, and show the overall level of satisfaction of both the individual employee and all surveyed employees of the examined organization. The three major indicators used in the evaluation of the motivational system are: pzo, PZO and PZOi.

The first one - pzo, shows the level of satisfaction from the motivational system of each individual employee.

$$
\mathrm{pzo}=\sum_{i=1}^{n}\left(\mathrm{~A}_{i}-\mathrm{B}_{i}\right)
$$

where:

$i$ - number of the question,

$n$ - the whole number of the questions in the part,

$A$ - value of the response in the question in part A,

$B$ - value of the response in the question in part $B$.

The second one - PZO helps to determine the overall level of satisfaction of all employees' expectations from the motivational system in an organization.

$$
\mathrm{PZO}=\sum_{i=1}^{n} \sum_{j=1}^{m}\left(\mathrm{~A}_{i j}-\mathrm{B}_{i j}\right)
$$

where:

$m$ - the whole number of the respondents,

$j$ - number of the questionnaire. 
What is more, it is possible to analyze each question separately. For this purpose, the $\mathrm{PZO}_{i}$ indicator is used.

$$
\mathrm{PZO}_{i}=\sum_{j=1}^{m}\left(\mathrm{~A}_{i j}-\mathrm{B}_{i j}\right), i=1,2, \ldots n
$$

Generally, the value of the indicator may vary within a range of (-6) to (6). However, if any measurement reaches a negative value, this indicates some irregularities within the motivational system in the organization.

Finally, part $\mathrm{C}$ of this questionnaire is used to identify the quality of the working environment offered by the organization. This section contains four pairs of factors connected closely with working conditions. For each pair of factors, the employee has indicated how often it is true that the first factor leads to the occurrence of a second one. The prime indicator of the questionnaire $\mathrm{C}$ is the arithmetic mean of all marks obtained from the questions in this section. If the arithmetic mean value is closer to 1 , there is a greater probability that the motivational system within the organization is ineffective and inadequate. Any deviations in part $\mathrm{C}$ indicate some kind of problems - these may result from improper work organization or mistakes during the recruitment of employees for the type of work they do (Mikuła 2001).

\subsection{Sample}

The research was conducted in February and March 2013 in a large hospital in the Małopolska province of Poland, which has functioned as an independent public healthcare institution since 1999 . The $5^{\text {th }}$ Military Hospital with Polyclinic in Krakow is a health care organization equipped with modern medical apparatus. It provides a full range of diagnostic, therapeutic, and rehabilitation treatment in modern laboratories and factories.(I don't understand in such a context) The profile of the hospital differs slightly from other hospitals in the Małopolska Province. The hospital currently treats patients in 22 branches. Its leading medical specialties include: Department of Cardiology, Department of Internal Medicine, Clinical Division of Traumatology and Orthopedics, Department of Clinical Ophthalmology, Department of Neurosurgery, and Department of Clinical Otolaryngology (where aggressive throat and larynx cancers are treated surgically). The hospital is the only one in Krakow with a department of Palliative Medicine. The aim of the personnel department is to provide the highest quality of life and help patients, especially in the final stage of the disease. Monthly, it takes care of about 3,000 patients, and more than 1,700 use the services of the hospital's emergency department. The hospital also secures the medical Polish armed peacekeeping mission in the United Nations and peacekeeping missions 
in the Polish Military Contingent in Afghanistan, the Republic of Iraq, Lebanon, Kosovo, Bosnia, and others (Kaczmarczyk, 2008).

The hospital employs 870 people for both medical and non-medical positions. The study used a random selection of the sample. From those employed in the hospital, the survey covered 87 employees, representing $10 \%$ of the total staff. The study involved 61 people employed in medical positions as well as 26 employed in non-medical positions. Among the participants were 60 women and 27 men. The study was fully anonymous, and the results are presented only in the form of indicators and statistics.

\section{Research results}

The analysis of the data indicated the PZO indicator - which explores the satisfaction level of all employees with the motivational system at a value of $(-2.26)$ - part A of the questionnaire. The index value informs us about the average level to meet the expectations of the surveyed employees. In order to expand further, results of the study other statistical values were calculated (see Tab. 1).

Table 1

Statistical values characterizing the degree of employee satisfaction with the motivational system

\begin{tabular}{|l|c|c|}
\hline \multicolumn{1}{|c|}{ Indicator - statistical value } & Symbol & Value \\
\hline Arithmetic mean & $\overline{\mathrm{x}}$ & -2.26 \\
\hline Standard deviation & $s$ & 1.65 \\
\hline Median & $M e$ & -2.35 \\
\hline Modal & $M o$ & -3.6 \\
\hline Asymmetry Index & $A s$ & 0.91 \\
\hline Coefficient of variation index & $V \mathrm{~s}$ & $73 \%$ \\
\hline Kurtosis & $K u$ & -1.20 \\
\hline Lower quartile & $Q_{1}$ & -3.64 \\
\hline Upper quartile & $Q_{3}$ & -0.70 \\
\hline Range & $R$ & 5.99 \\
\hline
\end{tabular}

Source: Based on the research results

The presented data shows that $50 \%$ of surveyed employees have a general level of satisfaction with the system PZO below the value of $(-2.35)$, while the rest of the surveyed employees are above this value. The received value of modal 
indicates that the largest group of surveyed employees are those whose level of satisfaction is $(-3.76)$. This means that the motivational system of the hospital meets employee expectations to a very small extent. The analysis of the average level of employee satisfaction from the system is insufficient. According to the indicators shown in table 1 , the value of the range for the surveyed group is 5.99. This informs us about the difference between employees with the highest and lowest degrees of satisfaction. The standard deviation for the group is 1.65, which indicates that the average level of employee satisfaction differs from the arithmetic mean by 1.65 , and therefore, ranges from the $(-0.61)$ to $(-3.91)$. Then, the received coefficient of variation index of $73 \%$ explains the significant level of differentiation in the level of employee satisfaction. Moreover, the results show that the test group of employees characterizes right-side asymmetry, which shows the density of statistical units with the variable less than the average. What is more, the low value for the kurtosis explains the flattening distribution curve and therefore, poor concentration around the arithmetic mean (Woźniak 2002).

Further analysis of employee satisfaction with the motivational system is connected with analyze(analysis?) of each question from the survey - part B of the questionnaire. The results are shown at the Figure 1.

\section{$P Z O_{i}$}

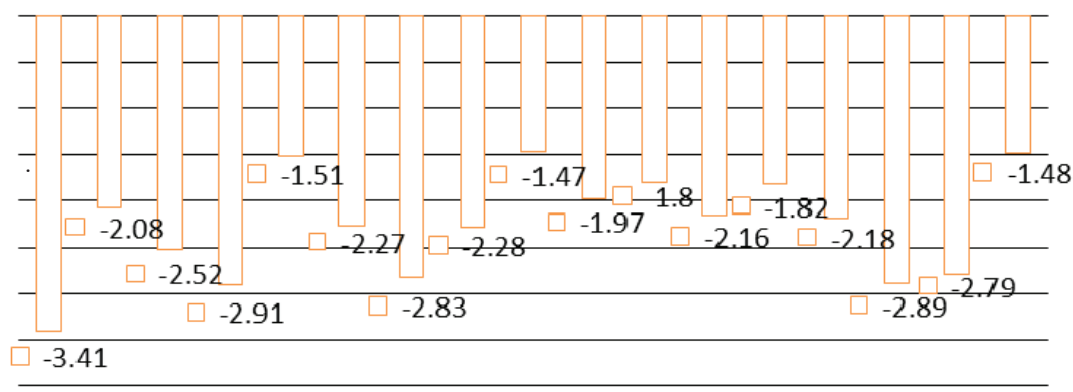

Figure 1. Employee satisfaction from each measure

Source: Based on the research results

From the analysis of Figure 1, it is assumed that the lowest level of satisfaction is related to question 1 - employee expectation of receiving an incentive pay $(-3.41)$. Then, job security - question 4 (-2.91) and rewards for special achievements (-2.89) - question 15. A slightly higher level of satisfying employee needs is associated with the possibility of promotion $(-2.83)-$ question 7 , as well as 
comfortable working conditions (-2.79) - question 15. The highest level of employee satisfaction among respondents referred to the larger autonomy at work $(-1.47)$ - question 9, then, the broader possibility of decision making and higher responsibility $(-1.51)$ - question 5 , and finally, working in special teams $(-1.48)$ - question 17.

Data from the last part of the questionnaire - part C - explored the overall work conditions and work organization in the hospital. The statistical measurements are provided below in the Table 2 .

Table 2

Statistical values characterizing the overall organization of work in the hospital

\begin{tabular}{|l|c|c|}
\hline \multicolumn{1}{|c|}{ Indicator - statistical value } & Symbol & Value \\
\hline Arithmetic mean & $\overline{\mathbf{x}}$ & 4.06 \\
\hline Standard deviation & $\mathrm{s}$ & 1.64 \\
\hline Median & $\mathrm{Me}$ & 4.00 \\
\hline Modal & $\mathrm{Mo}$ & 4.00 \\
\hline Asymmetry Index & $\mathrm{As}$ & 0.03 \\
\hline Coefficient of variation index & $\mathrm{V}_{\mathrm{s}}$ & $40 \%$ \\
\hline Kurtosis & $\mathrm{Ku}$ & -0.75 \\
\hline Lower quartile & $\mathrm{Q}_{1}$ & 3.00 \\
\hline Upper quartile & $\mathrm{Q}_{3}$ & 5.25 \\
\hline
\end{tabular}

Source: Based on the research results

The obtained value of the arithmetic mean shows that there are no critical errors in work organization in the hospital, and employees are selected respectively in terms of competences and demands in the work they perform. While the standard deviation is $\mathbf{1 . 6 4}$, which means that the evaluation of the overall work organization differs from the arithmetic mean of about 1.64 and, therefore, varies from 2.42 to 5.70 . In turn, the median means that $50 \%$ of employees evaluate the work organization below 4.00 , while $50 \%$ of those surveyed were above this value. Mode is equal to the median and reaches the value of 4.00. It differs slightly from the arithmetic mean (4.06). Finally, the value of the asymmetry factor is close to 0 , as it is 0.03 . Those factors raise the supposition of the existence of a normal distribution. The coefficient of variation index (which is $40 \%$ ) indicated quite a significant dispersion of the results obtained on the overall situation of the organization of work in the hospital, as its value is higher than $20 \%$. Then, the value obtained for kurtosis (which is [-0.75]) shows a slight flattening 
of distribution. Moreover, $25 \%$ of respondents assess the overall situation of the work organization below the value of 3.00 , and $75 \%$ of respondents assessed this matter above this value. In turn, the top quartile shows that $25 \%$ of respondents assess the overall situation of work organization above the value of 5.25.

\section{Conclusions}

The results of the analysis of the motivational system in the hospital in Krakow clearly indicate a relatively proper system design and good organization of work. Unfortunately, the effectiveness of this system, which means satisfaction of the needs and expectations of the hospital employees assessed in this regard, seems very low. Judging by the results obtained, it is hard to talk about any satisfaction of employees with the applied motivational system.

Analyzing the motivational system of the hospital, the lowest-rated elements were classified as hygiene factors; for example, rewards, salary, or job security. Moreover, the occurrence of the so-called demotivational factors can also be observed, such as stress at work and organizational changes (to some extent). These adverse environmental conditions do not outweigh the common motivators at work, like opportunities for promotion or professional development as well as the content of the work itself, which occurs mainly among the hospital medical staff. These results are consistent with earlier studies in other European countries (Kautsch 2010; Report of the European Foundation... 2009), which underlined the low quality of working life and dissatisfaction of employees from working conditions in the health care sector. The lowest-rated aspects of the motivational system are associated with financial motivation as the possibility of getting incentive pay or financial reward. However, the lowest satisfaction of the employees in the examined hospital was connected with the total compensation package, which includes pay level, incentives and bonuses, long-term incentives, or other benefits that employees can receive.

In times of economic crisis, almost every employer is looking for savings and seeks to minimize wage costs. Despite constant cooperation with the Division of National Health Fund, the current financial situation of the hospital is very dire. Therefore, modifications in the current motivational system are viewed as an expensive and very challenging process. One possible solution would be to establish an incentive system created on the basis of the results achieved by an individual organizational unit of the hospital.

One solution for financial reward could be the so-called pay for performance system. It is a system used in health care on a large scale in the United States and Great Britain. However, the application of the system of pay for performance 
$(\mathrm{P} 4 \mathrm{P})$ is very difficult, and is associated with a clarification of a number of elements affecting quality and efficiency of the medical staff (Suchecka, Budny 2012, pp. 51). In this context, funds provided for bonuses in the hospital should depend on the level of the results obtained by any given organizational unit, the level of costs of the organizational unit, and the execution of the task. Then, distribution of the incentive funds should be made on the basis of performance appraisal. Furthermore, parallel to the financial motivation, the non-financial elements of the system should also be improved. For example, a well-designed range of additional benefits (in the form of a cafeteria plan) could be beneficial for both the hospital as well as its employees. The cafeteria plan could include such benefits as sabbaticals, additional non-working days, or four-day work-weeks during any given period.

In order to meet the needs of an aging population and increased demand for health care services in the future, the motivational aspects of the working environment in this sector will require significant improvements. However, to make more versatile applications, it would be useful to examine the satisfaction of employees with motivational systems applied in the health care sector in other hospitals in Poland.

\section{References}

[1] Armstrong M., Brown D., Reilly P. 2011, Increasing the effectiveness of reward management: an evidence-based approach, "Employee Relations", vol. 33, (2), pp. 106-120.

[2] Armstrong M., Cummins A. 2010, The Reward Management Toolkit, Kogan Page, London.

[3] Bartkowiak G. 2008, Motywowanie personelu i zarzadzanie kompetencjami $w$ zakladach opieki zdrowotnej, in: Podstawy zarzadzania zakładem opieki zdrowotnej, M. Dobska, K. Rogoziński (eds), Wydawnictwo Naukowe PWN, Warszawa.

[4] Beck-Krala E. 2013, Wynagrodzenia pracowników w organizacji. Teoria i praktyka, Wydawnictwa AGH, Kraków.

[5] Borkowska S. 2012, Skuteczne strategie wynagrodzeń - tworzenie i zastosowanie, Wolters Kluwer Polska, Warszawa.

[6] Brown D. 2008, Measuring the effectiveness of pay and rewards: the Achilles' beel of contemporary reward professionals, "Compensation and Benefits Review”, vol. 40 (5), pp. 23.

[7] Corby S., White G., Stanworth C. 2005, No news in good news? Evaluating new pay systems, "Human Resources Management Journal", vol. 15 (1), pp. 4-24. 
[8] Golinowska S., Czepulis-Rutkowska Z., Sitek M., Sowada Ch., Włodarczyk C., Sowa A. 2002, Opieka zdrowotna $w$ Polsce po reformie, CASE, Warszawa.

[9] Juchnowicz M. 2011, Dylematy oceny efektywności wynagrodzeń $w$ organizacji gospodarczej, in: Efektywność gospodarowania kapitalem ludzkim, P. Bohdziewicz (ed.), Wydawnictwo Uniwersytetu Łódzkiego, Łódź.

[10] Kaczmarczyk D. 2008, Dzieje i tradycje 5 Wojskowego Szpitala Klinicznego $z$ Poliklinika $w$ Krakowie, referat wygłoszony w 90. rocznicę powstania Szpitala Wojskowego w Krakowie w 2008 r., materiały niepublikowane.

[11] Karaszewska H., Nieżurawska J. 2013, Wynagradzanie lekarzy w podmiotach leczniczych w Polsce, "Zarządzanie Zasobami Ludzkimi”, vol. 5, pp. 61-75.

[12] Kautsch M. 2010, Specyfika zarzadzania zakładem opieki zdrowotnej, in: Zarzadzanie $w$ opiece zdrowotnej. Nowe wyzwania, M. Kautsch (ed.), Wolters Kluwer Polska Sp z o.o., Warszawa.

[13] Kopertyńska W. 2004, System ocen przedsiębiorstwa a jego powiązanie z wynagrodzeniem, in: ZZL w warunkach nowej gospodarki, A. Pocztowski, Z. Wiśniewski (eds), Oficyna Ekonomiczna, Kraków.

[14] Mikuła B. 2001, Elementy nowoczesnego zarządzania. W kierunku organizacji inteligentnych, Oficyna Wydawnicza ANTYKWA s.c., Kraków.

[15] Report of the European Foundation for the Improvement of Living and Working Conditions - employment and industrial relations in the bealth care sector 2009, Dublin, Irleand.

[16] Scott D., Morajda D., McMullen T. 2009, Evaluating pay program effectiveness, "WorldatWork Journal", 15(2), pp. 50-59.

[17] Suchecka J., Budny D., Olszewski W. 2012, Pay for performance (P4P) jako programy motywacyjnego wynagradzania za wyniki $w$ opiece zdrowotnej: wybrane aspekty, in: Racjonalizacja kosztów w ochronie zdrowia, E. Nojszewska (ed.), Wolters Kluwer, Warszawa.

[18] Ustawa z dnia 30 sierpnia 1991 o zakładach opieki zdrowotnej (Dz. U. 2007 r., Nr 14, poz. 89 z późn. zm.)

[19] Ustawa o izbach lekarskich z dnia 2 grudnia 2009 roku (Dz. U. 2009 r., Nr 219, poz. 1708 z późn. zm.)

[20] Woźniak M., Zając K. 2020, Istota i przedmiot badań statystycznych. Prezentacja danych, in: Statystyka ogólna, M. Woźniak (ed.), 3d ed., Wydawnictwo Akademii Ekonomicznej w Krakowie, Kraków. 